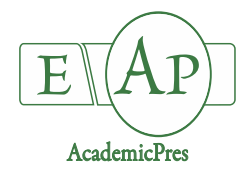

Szekely-Varga Z et al. (2020)

Notulae Botanicae Horti Agrobotanici Cluj-Napoca 48(4):1980-1992

DOI: $10.15835 / 48412150$

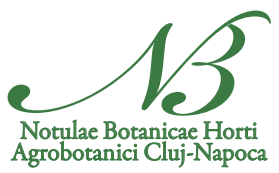

\title{
Antioxidant responses to drought and salinity in Lavandula angustifolia Mill.
}

\author{
Zsolt SZEKELY-VARGA ${ }^{1,2}$, Sara GONZÁLEZ-ORENGA3, \\ Maria CANTOR ${ }^{1 *}$, Monica BOSCAIU ${ }^{3 *}$, Oscar VICENTE ${ }^{2}$ \\ ${ }^{1}$ University of Agricultural Sciences and Veterinary Medicine of Cluj-Napoca, Faculty of Horticulture, 400372 Cluj-Napoca, \\ Romania; zsolt.szekely-varga@usamvcluj.ro; maria.cantor@usamvcluj.ro \\ ${ }^{2}$ Universitat Politècnica de València, Institute for the Conservation and Improvement of Valencian Agrodiversity (COMAV), \\ Camino de Veras/n, 46022 Valencia, Spain; ovicente@upvnet.upv.es \\ ${ }^{3}$ Universitat Politècnica de València, Mediterranean Agroforestry Institute(IAM), Camino de Vera s/n, 46022 Valencia, Spain; \\ mobosnea@eaf.upv.es (*corresponding author);sagonor@etsia.upv.es
}

\begin{abstract}
Drought and salinity are amongst the most damaging environmental stressors that can affect a plant's life cycle, from germination to senescence. In the present study were analysed the responses to salinity and drought in greenhouse-controlled conditions of two varieties of Lavandula angustifolia. Three-month-old lavender seedlings were subjected to water deficit and salt stress $(100,200$ and $300 \mathrm{mM} \mathrm{NaCl})$ during a 30-day period. Complementing a previous analysis focused on stress tolerance mechanisms based on the regulation of ion transport and the synthesis of osmolytes, we have now evaluated the effects of the water deficit and salt treatments on the generation of secondary oxidative stress, by measuring malondialdehyde levels, and the activation of antioxidant systems, both non-enzymatic and enzymatic, determining total phenolic compounds and flavonoids contents and calculating superoxide dismutase, catalase, ascorbate peroxidase and glutathione reductase specific activities, respectively, in extracts of control and stressed plants. The results obtained confirm that both lavender varieties react in the same way to the applied stress treatments, activating the same antioxidant responses. However, some differences were observed when comparing the specific mechanisms triggered by each type of stress. Thus, the oxidative stress induced under drought conditions was counteracted by accumulation of phenolic compounds and flavonoids, without apparent involvement of antioxidant enzymes. Salt stress, on the other hand, in addition to an increase in flavonoid levels also induced superoxide dismutase and catalase activities. These antioxidant responses are likely to contribute to the relatively high tolerance (as compared to most crops) of lavender to drought and salinity.
\end{abstract}

Keywords: abiotic stress; antioxidant enzymes; oxidative stress; Lamiaceae, non-enzymatic antioxidants; reactive oxygen species

\section{Introduction}

Drought is becoming a major environmental challenge in many areas of the world, imposing the need for irrigation, which is eventually causing soil salinisation (Fahad et al., 2017). Such environmental changes, 
which pose a serious threat to agriculture, have also been reported in Romania (Croitoru et al., 2016; Irimia et al., 2018; Prăvălie et al., 2020).

Plants are exposed to a wide range of environmental stress conditions (salinity, drought, extreme temperatures), which negatively affect their growth and may even prevent the completion of their life cycle (Kaur and Asthir, 2016; Forni et al., 2016; Nareshkumar et al., 2020). Under stress conditions, plants activate their defence mechanisms, including physiological, biochemical, and molecular responses (Bartels and Ramanjulu, 2005; Forni et al., 2016; Acosta-Motos et al., 2017; Mittal et al., 2018; Rao et al., 2019). Drought and salinity, as well as other abiotic and biotic stresses, alter the metabolic activity of the cell by producing an excessive amount of reactive oxygen species (ROS) (Aftab, 2019). Although ROS are toxic when in excess, they are important signalling molecules and have a role in regulating biological processes from germination to senescence (Miller et al., 2008; Morales and Munné-Bosch, 2019). The accumulation of ROS triggers antioxidant mechanisms that include the accumulation of antioxidant compounds, such as phenols and flavonoids, amongst others, and the activation of antioxidant enzyme systems, such as catalase (CAT), superoxide dismutase (SOD), ascorbate peroxidase (APX) (and other peroxidases), and glutathione reductase (GR) (Sharma et al., 2012).

Lavandula is a genus of the Lamiaceae family, native to the Mediterranean region. It includes over 45 species and some 400 varieties (Benabdelkader et al., 2011; The Plant List, 2020), many of which are prized for their aromatic oils as medicinal and ornamental plants (Biesiada and Kucharska, 2008; Lis-Balchin 2012; Mokhtarzadeh et al., 2013; Prusinowska and Śmigielski, 2014; Carrasco et al., 2016; Matysiak and Nogowska, 2016). In terms of environmental requirements, most lavender species and varieties grow well in a wide range of climatic conditions (Lis-Balchin, 2002; Upson and Andrews, 2004; Adam, 2006; Wells et al., 2018), but their ecological optimum is found in regions with warm, sunny summers and cold winters (Lis-Balchin, 2002).

Lavandula angustifolia Mill. is a perennial shrub, which can grow from $23 \mathrm{~cm}$ to $90 \mathrm{~cm}$, and has a lifespan of 20-30 years, depending on the mode of cultivation (Koulivand et al., 2013; Seidler-Àoìykowska et al., 2014). Large-scale lavender cultivation flourished in the 17th century in Spain, France, and Italy, while in Central and Eastern Europe, in countries such as Romania, Bulgaria, Hungary, and Poland, cultivation began only in the 20th century (Pisulewska et al., 2009).

Two varieties of lavender were subjected to water deficit (complete withholding of irrigation) and salt stress (watering the plants with increasing $\mathrm{NaCl}$ concentrations) in our experimental set-up: Lavandula angustifolia var. 'Codreanca' (LAC) from Romania, and var. 'Sevtopolis' (LAS) from Bulgaria. Their growth responses, together with an analysis of the uptake and transport of ions to the leaves and the accumulation of osmolytes have been published previously (Szekely-Varga et al., 2020). The aim of the present study was to investigate the effects of the applied drought and salinity treatments on the generation of oxidative stress and the activation of antioxidant mechanisms in the two cultivars. The degree of oxidative stress suffered by the plants was evaluated by measuring the accumulation of malondialdehyde (MDA). As representative nonenzymatic antioxidants, the leaf contents of total phenolic compounds (TPC) and total flavonoids (TF) were determined, and the specific activities of the main antioxidant enzymes, superoxide dismutase (SOD), catalase (CAT), ascorbate peroxidase (APX) and glutathione reductase (GR) were in turn measured.

\section{Materials and Methods}

\section{Plant material and stress treatments}

In this work, two varieties of Lavandula angustifolia were used as experimental material. L. angustifolia var. 'Codreanca' (LAC) is a Romanian variety approved in 1992; it reaches up to $60 \mathrm{~cm}$ high, and a width of 60-70 cm, with silvery blue leaves. It produces blue-purple flowers, sometimes deep blue, which bloom in May-

June. LAC is considered one of the best varieties for Romania's climatic conditions and is resistant to low temperatures and even frost (Cantor et al., 2018). The second analysed lavender variety was L. angustifolia var. 
'Sevtopolis' (LAS), native to Bulgaria. It reaches a height of 40-60 cm, and a width of 50-60 cm. It has blue flowers and greyish green leaves and a great commercial interest due to its high content in essential oils (Kivrak, 2018). Both varieties are grown mainly for the extraction of essential oils, but they also have ornamental value, and can be used as cut flowers.

Seedlings of both lavender varieties were grown individually in $0.3 \mathrm{~L}$ plastic pots with a mixture of $50 \%$ peat, $25 \%$ perlite and $25 \%$ vermiculite. Throughout the experiment, the plants were kept in a climatecontrolled chamber, under artificial light with a long daytime photoperiod (16 hours of light and 8 hours of darkness), and light intensity of $130 \mu \mathrm{E} \mathrm{m}^{-2} \mathrm{~s}^{-1}$, at a constant temperature of $23^{\circ} \mathrm{C}$ and $60-80 \%$ relative humidity. For each treatment, five pots of each cultivar were placed separately in a plastic tray. Until the treatments began, the lavender seedlings were watered every three days with Hoagland nutrient solution (Hoagland and Arnon, 1950). The treatments were started after 3 months from planting, when the development of the seedlings of the two lavender varieties corresponded to the main growth stage 4 according to the $\mathrm{BBCH}$ coding system (Meier, 2001). Treatments were applied by watering the plants twice a week with $\mathrm{NaCl}$ solutions of final concentrations of 0 (for the controls), 100, 200 and $300 \mathrm{mM}$, adding $1 \mathrm{~L}$ of solution per tray. For water stress treatments (WS), irrigation was completely withheld. The treatments were stopped after 30 days. Plant samples (roots, stems and leaves) were collected. Five individual lavender plants of each variety per treatment were used as biological replicates.

\section{Malondialdehyde (MDA)}

Malondialdehyde (MDA) concentration was determined in aqueous methanol extracts $(80 \%, \mathrm{v} / \mathrm{v})$, prepared by grinding $0.05-0.10 \mathrm{~g}$ of fresh lavender leaves, and centrifuging the samples at 12,000 rpm for 15 min. MDA was quantified in the supernatants, as previously described (Hodges, 1999). Each sample was mixed with $0.5 \%(\mathrm{w} / \mathrm{v})$ thiobarbituric acid (TBA) prepared in $20 \%(\mathrm{w} / \mathrm{v})$ trichloroacetic acid (TCA)-or with $20 \%$ TCA without TBA for the controls-and then incubated at $95^{\circ} \mathrm{C}$ for $15 \mathrm{~min}$, in a water bath. The reactions were stopped on ice, the samples were centrifuged at $12,000 \mathrm{rpm}$ for $10 \mathrm{~min}$, at $4{ }^{\circ} \mathrm{C}$, and the absorbance of the supernatants was measured at $532 \mathrm{~nm}$. After subtracting the non-specific absorbance at 600 and $440 \mathrm{~nm}$, the MDA concentration was calculated applying the equations described by Hodges (Hodges, 1999) based on the molar extinction coefficient of the MDA-TBA adduct at $532 \mathrm{~nm}\left(\varepsilon_{532}=155 \mathrm{mM}^{-1} \mathrm{~cm}^{-1}\right)$.

\section{Non-enzymatic antioxidants}

Total phenolic compounds (TPC) and total flavonoids (TF) concentrations were determined in the same $80 \%$ methanol extracts used for MDA measurements. TPC were determined according to the protocol of Blainski (Blainski et al., 2013), which is based on the reaction with the Folin-Ciocalteu reagent, in the presence of $\mathrm{NaHCO}_{3}$; the reaction mixtures were incubated at room temperature, in the dark, for $90 \mathrm{~min}$, and the absorbance was then recorded at $765 \mathrm{~nm}$. TPC concentration was expressed as equivalents of the standard, gallic acid (mg eq. $\left.\mathrm{GA} \mathrm{g}^{-1} \mathrm{DW}\right)$.

TF were determined by nitration of catechol groups with $\mathrm{NaNO}_{2}$, followed by reaction with $\mathrm{AlCl}_{3}$ under alkaline conditions (Zhishen et al., 1999). The absorbance of the samples was read at $510 \mathrm{~nm}$, using catechin as the standard. TF concentration was expressed as equivalents of catechin (mg eq. $\mathrm{C} \mathrm{g}^{-1} \mathrm{DW}$ ).

\section{Antioxidant enzyme activities}

The specific activity of four major antioxidant enzymes, namely, superoxide dismutase (SOD), catalase (CAT), ascorbate peroxidase (APX), and glutathione reductase (GR), was determined at room temperature ( $25^{\circ} \mathrm{C}$ ) in crude protein extracts prepared from lavender leaves, as previously described (Gil et al., 2014). The plant material was ground in liquid $\mathrm{N}_{2}$ and mixed with extraction buffer $[20 \mathrm{mM}$ Hepes, $\mathrm{pH}=7.5,50 \mathrm{mM}$ $\mathrm{KCl}, \quad 1 \mathrm{mM}$ EDTA, $0.1 \%(\mathrm{v} / \mathrm{v})$ Triton X-100, $0.2 \%(\mathrm{w} / \mathrm{v})$ polyvinylpyrrolidone, $0.2 \%(\mathrm{w} / \mathrm{v})$ polyvinylpolypyrrolidone and $5 \%(\mathrm{v} / \mathrm{v})$ glycerol]; to improve protein extraction, $1 / 10$ volume of 'high salt buffer' (225 mM Hepes, pH 7.5, $1.5 \mathrm{M} \mathrm{KCl}$ and $22.5 \mathrm{mM} \mathrm{MgCl}_{2}$ ) was added to the samples, mixed well by 
vortexing and kept $15 \mathrm{~min}$ on ice. After centrifugation at $13,500 \mathrm{rpm}$ for $15 \mathrm{~min}$ at $4{ }^{\circ} \mathrm{C}$, the supernatants were collected, concentrated in U-Tube concentrators (Novagen, Madison, WI, USA), and centrifuged again to remove precipitated material. The supernatants, referred to as 'protein extracts' were frozen in liquid $\mathrm{N}_{2}$, and stored in aliquots at $-75^{\circ} \mathrm{C}$. Protein concentration in the extracts was measured by the method of Bradford (Bradford, 1976), using the Bio-Rad reagent and bovine serum albumin (BSA) as standard.

SOD activity in the protein extracts was determined at $560 \mathrm{~nm}$ following the inhibition of nitroblue tetrazolium (NBT) photoreduction in reaction mixtures containing riboflavin as the source of superoxide radicals (Beyer, 1987). A SOD unit was defined as the amount of enzyme that causes $50 \%$ inhibition of NBT photoreduction under the assay conditions.

Catalase (CAT) activity was assessed by the decrease in absorbance at $240 \mathrm{~nm}$, which parallels the consumption of $\mathrm{H}_{2} \mathrm{O}_{2}$ added to the extracts (Aebi, 1984). A CAT unit was defined as the amount of enzyme that will decompose one mmol of $\mathrm{H}_{2} \mathrm{O}_{2}$ per minute at $25^{\circ} \mathrm{C}$.

The enzymatic activity of ascorbate peroxidase (APX) was determined by the decrease in absorbance observed at $290 \mathrm{~nm}$ as ascorbate becomes oxidised in the reaction (Nakano and Asada, 1981). One APX unit was defined as the amount of enzyme required to consume one mmol of ascorbate per minute, at $25^{\circ} \mathrm{C}$.

Glutathione reductase (GR) activity was quantified according to Conell and Mullet (Conell and Mullet, 1986), following the decrease in absorbance at $340 \mathrm{~nm}$ due to oxidation of NADPH - the cofactor of the GRcatalysed reduction of oxidised glutathione (GSSG). One GR unit was defined as the amount of enzyme that will oxidise one mmol of NADPH per minute, at $25^{\circ} \mathrm{C}$.

\section{Statistical analysis}

Data were analysed using Statgraphics Centurion XVI (Statgraphics Technologies, The Plains, VA, USA). Before the analysis of variance, a Shapiro-Wilk test was used to check for the validity of normality assumption and a Levene's test was used for the homogeneity of variance. If ANOVA requirements were met, significant differences among treatments were tested by one-way ANOVA at the $95 \%$ confidence level, and post hoc comparisons were made using a Tukey HSD test. All mean values throughout the text, followed by their SE, are based on five biological replicas per variety and per treatment.

\section{Results}

\section{Oxidative stress}

Malondialdehyde (MDA) concentrations were determined in leaf extracts of the lavender seedlings subjected to water and salt stress treatments (Figure 1). Under our experimental conditions, after 30 days without watering the plants, average MDA content decreased with respect to the control in the LAC variety, whereas an increase was observed in LAS seedlings (Figure 1). On the other hand, the salt treatments induced a considerable increase in MDA contents in both varieties. Average MDA values in salt-stressed plants of both varieties were significantly higher than in those from control (Figure 1).

\section{Non-enzymatic antioxidants}

Total phenolic compounds (TPC) (Figure 2a) and total flavonoids (TF) (Figure 2b) were quantified in all leaf samples collected from the two lavender varieties in the presence of the indicated $\mathrm{NaCl}$ concentrations $(100,200$ and $300 \mathrm{mM} \mathrm{NaCl})$ or under water deficit stress (WS) for 30 days. No significant differences were observed between the two varieties for any of the treatments, neither in TPC (Figure 2a) nor in TF (Figure 2b) contents.

In both lavender varieties, a significant increase in TPC contents was detected in the water-stressed plants. In response to the salt stress treatments, a relatively smaller, but still statistically significant increase in 
TPC was found in LAC, but no significant changes with respect to the control were observed in the LAS (Figure 2a).

Under our experimental conditions, TF contents recorded significant increases in water deficit and salt stress compared to the control in the two lavender varieties. In both, the greatest increase was observed in plants subjected to water stress treatments (Figure $2 \mathrm{~b}$ ).

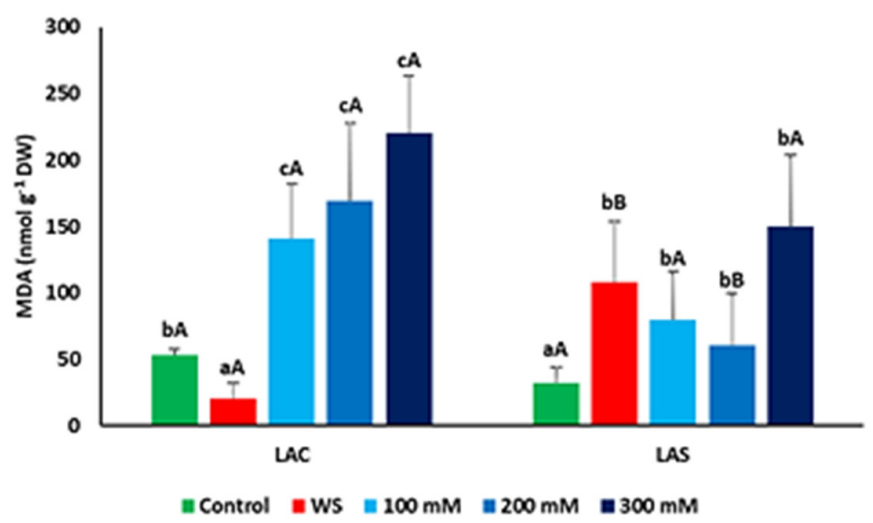

Figure 1. Malondialdehyde (MDA) levels in leaves of L. angustifolia var. 'Codreanca' (LAC) and var. 'Sevtopolis' (LAS) seedlings after 30 days of growth in the presence of the indicated $\mathrm{NaCl}$ concentrations or subjected to water deficit stress (WS)

Bars represent means $\pm S E(n=5)$. Different lowercase letters above the bars indicate significant differences between treatments for each variety, and different uppercase letters indicate significant differences between the two varieties for plants undergoing the same treatment, according to the Tukey test $(\alpha=0.05)$.

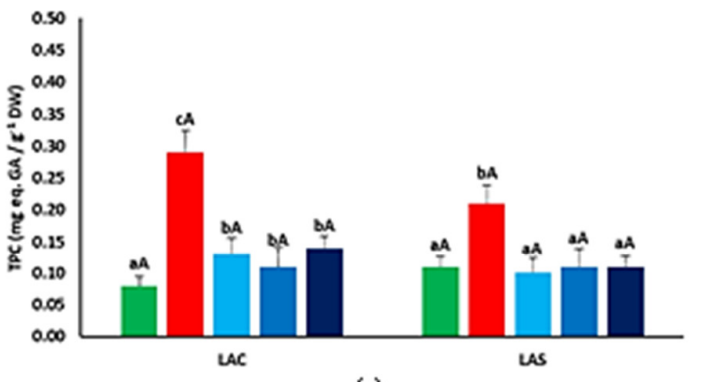

(a)

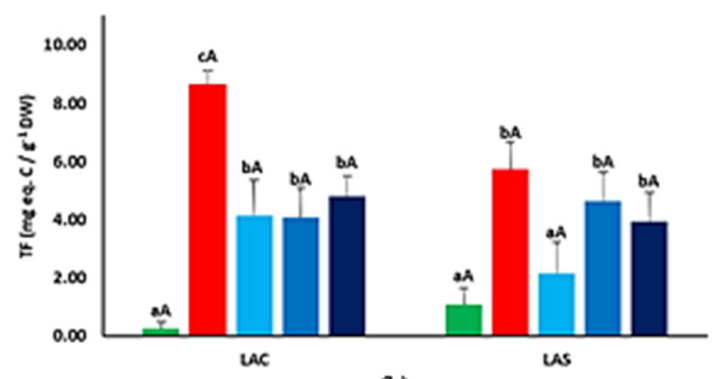

(b)

EControl $=W S=100 \mathrm{mM}=200 \mathrm{mM}=300 \mathrm{mM}$

Figure 2. Total phenolic compounds (TPC) (a) and total flavonoids (TF) (b) leaf contents of $L$. angustifolia var. 'Codreanca' (LAC) and var. 'Sevtopolis' (LAS) seedlings, after 30 days of growth in the presence of the indicated $\mathrm{NaCl}$ concentrations or subjected to water deficit stress (WS)

Bars represent means $\pm S E(n=5)$. Different lowercase letters above the bars indicate significant differences between treatments for each variety, and different uppercase letters indicate significant differences between the two varieties for plants undergoing the same treatment, according to the Tukey test $(\alpha=0.05)$.

\section{Antioxidant enzyme activities}

The specific activities of some of the most relevant antioxidant enzyme systems: superoxide dismutase (SOD), catalase (CAT), ascorbate peroxide (APX) and glutathione reductase (GR), were determined by spectrophotometric assays, using protein extracts prepared from leaves of the control and stressed lavender seedlings.

A significant increase in SOD specific activity was observed in the lavender seedlings subjected to salt stress, but not to water deficit; SOD variation patterns were similar in the two varieties, which did not show 
significant differences in any of the treatments (Figure 3a). Similarly, for both varieties, CAT activity did not change in water-stressed plants, with respect to the corresponding controls, whereas it increased significantly in response to the salt treatments (Figure $3 \mathrm{~b}$ ). It should be notice that the average CAT activity was generally lower in LAS plants than in the LAC variety, for each specific treatment, although with statistically significant differences between varieties observed only in the controls and in the $300 \mathrm{mM} \mathrm{NaCl}$ treatment (Figure 3b). In the variety LAS, the APX specific activity did not vary significantly, as compared to the control, in any of the salt treatments, or under water deficit conditions (Figure 3c). On the other hand, plants of the LAC variety subjected to salt stress showed a strong decrease in APX activity, whereas it did not vary in water-stressed plants (Figure 3c). Regarding GR specific activity, both varieties showed a significant decrease in response to watter stress; on the contrary, GR activity increased with respect to the control in the presence of high salt concentrations $(300 \mathrm{mM} \mathrm{NaCl})$, but only in the LAS variety (Figure 3d).

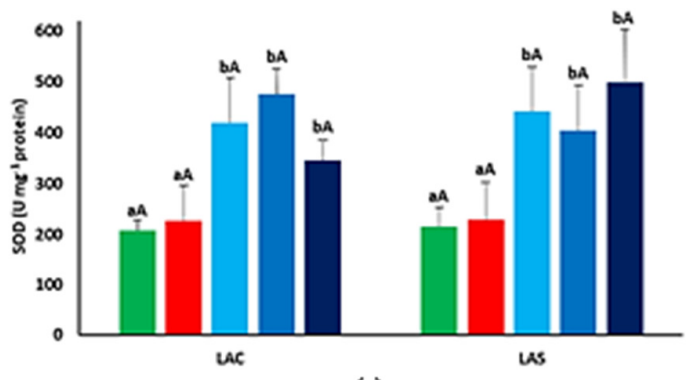

(a)

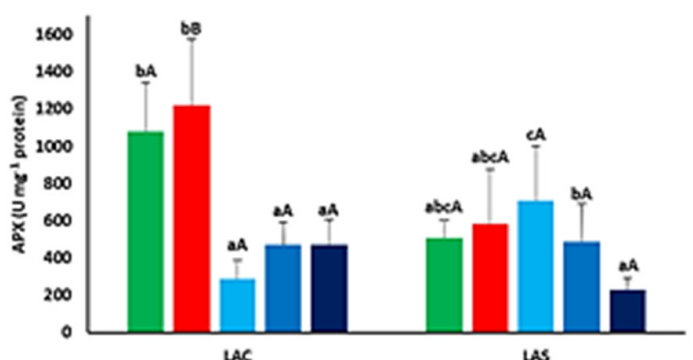

(c)

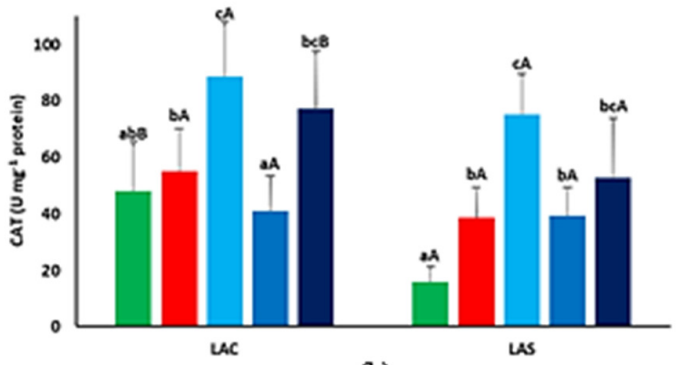

(b)

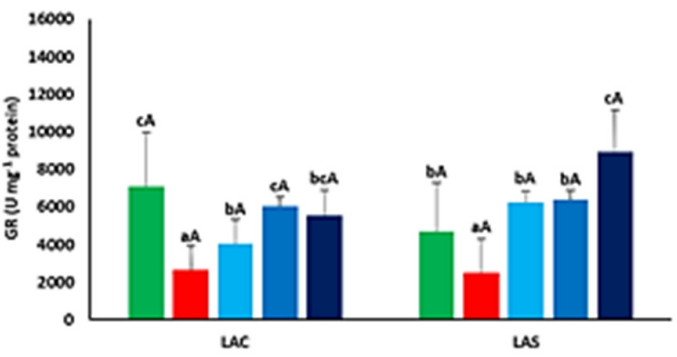

(d)

$=$ Control $=W S=100 \mathrm{mM}=200 \mathrm{mM}=300 \mathrm{mM}$

Figure 3. Antioxidant enzyme activities: superoxide dismutase (SOD) (a), catalase (CAT) (b), ascorbate peroxidase (APX) (c) and glutathione reductase (GR) (d) in leaves of L. angustifolia var. 'Codreanca' (LAC) and var. 'Sevtopolis' (LAS) seedlings after 30 days of growth in the presence of the indicated $\mathrm{NaCl}$ concentrations or subjected to water deficit stress (WS)

Bars represent means \pm SE $(n=5)$. Different lowercase letters above the bars indicate significant differences between treatments for each variety, and different uppercase letters indicate significant differences between the two varieties for plants undergoing the same treatment, according to the Tukey test $(\alpha=0.05)$.

\section{Discussion}

The results of the present study confirm previous data (Szekely-Varga et al., 2020), clearly indicating that the responses to water deficit and salt stress of the two selected varieties of $L$. angustifolia, 'Codreanca' (LAC) and 'Sevtopolis' (LAS), were very similar. Lavender growth was significantly reduced with increased salt concentration and under water deficit conditions, which influenced the plant biomass; however, all plants survived the strong stress conditions applied, indicating that lavender is relatively tolerant to both, drought and 
salinity. Growth inhibition is a very general response to stress, as plants under stressful conditions reallocate their growth and primary metabolism resources to the activation of defence mechanisms (Munns and Tester, 2008; Hendawy and Khalid, 2005). The study mentioned above (Szekely-Varga et al., 2020), focused on the effects of the stress treatments on growth, ion transport and osmolyte accumulation in plants of the two lavender varieties. We reported some variations in the mean values of several growth parameters; however, the differences were too small to allow considering any of the two varieties as more stress-tolerant than the other. In the two varieties, the most relevant mechanisms activated in response to salt stress, which are likely to be involved in salt tolerance in this species, were the maintenance of foliar $\mathrm{K}^{+}$levels and the accumulation in leaves of $\mathrm{Ca}^{2+}$, and of proline as a functional osmolyte; in the case of water stress, an osmotic adjustment with significant increases in root $\mathrm{Na}^{+}$and $\mathrm{K}^{+}$concentrations is presumably limiting root dehydration. The present work aimed at extending and complementing those previous results, investigating the possible contribution of antioxidant responses to the mechanisms of drought and salt tolerance in lavender.

Reactive oxygen species (ROS) are ubiquitous in plants under stress (Abogadallah, 2010; Nareshkumar et al., 2020). They are produced by plants as by-products during various metabolic reactions, for example, photosynthesis and respiration, and play essential roles in cell signalling and homeostasis (Van Breusegem et al., 2001; Ahmad et al., 2010). ROS are produced in excess in response to different stresses, and overproduction of ROS can lead to membrane lipid peroxidation, which is often quantified by measuring the levels of malondialdehyde (MDA), a product of this reaction and a reliable marker of oxidative stress (Del Rio et al., 1996).

In the present study, in general, no significant differences in MDA levels were observed between the two selected varieties in any of the treatments, indicating a similar degree of drought- or salt-induced oxidative stress in both of them. However, analysing the mean values of MDA contents in the different treatments, some quantitative differences were observed. For example, high levels of MDA were found in the Bulgarian variety 'Sevtopolis', both under water and salt stress conditions, whereas in the 'Codreanca' variety, MDA increased only in salt-stressed plants. The low MDA concentration observed under water stress in plants of the LAC variety suggests that, concerning specifically antioxidant responses, it probably adapts slightly better to drought than the LAS variety, since it has a better defence against the harmful effect of oxidative stress associated with drought (Zhou et al., 2017). In contrast, its higher MDA concentrations measured under low and moderate ( 100 and $200 \mathrm{mM} \mathrm{NaCl}$ ) salt stress conditions, may indicate that 'Codreanca' is somewhat more susceptible to salt-associated oxidative stress than the 'Sevtopolis' variety. Similar results underlying the reliability of MDA as a marker of oxidative stress have been obtained by many different authors in plants subjected to various stress factors, for example, by Xia et al. (2020) (kiwi); Goharrizi et al. (2020) (Lepidium draba); Nareshkumar et al. (2020) (cucumbers, tobacco and rice); or Arora et al. (2020) (Artemisia annua).

Phenolic compounds, and especially the subgroup of flavonoids, play multiple roles in plants, including their adaptation to stressful conditions (Shah and Smith, 2020). Since most flavonoids and many other phenolics are strong antioxidants, their accumulation can be related to the reduction of oxidative damage and thus to an increased tolerance to stress (Hussain et al., 2013; Al Hassan et al., 2017). Both, total phenolic compounds (TPC) and total flavonoids (TF) contents increased significantly under water stress conditions in both varieties, although the relative increase over the corresponding controls, and the absolute mean values reached at the end of the water deficit treatment, were higher in the LAC variety. Accumulation of these antioxidant compounds to higher concentrations may explain the (slightly) stronger antioxidant response of the LAC variety suggested by the MDA concentration patterns. Regarding the salt treatments, an increase in TF was observed in the two varieties, LAC and LAS, albeit to lower levels than those reached in the water stress treatments, indicating a significant contribution of flavonoids to the antioxidant responses of lavender to salinity. This effect, however, seems to be masked by other phenolic compounds since TPC contents increased only slightly in response to salt stress in the LAC variety, and not at all in LAS seedlings. These results are in agreement with many published reports supporting the functional role of antioxidant flavonoids and other phenolics in the responses of plants to drought, salinity and other environmental stress conditions generating 
oxidative stress, either directly or as a secondary effect (e.g., Sharma et al., 2012; Hussain et al., 2013; Al Hassan et al., 2017). In fact, several authors have suggested that the accumulation of phenolic compounds and flavonoids could have been a key step in the evolution of plants towards tolerance to different stress factors (Bautista et al., 2016; Sharma et al., 2016; Rodríguez-Calzada et al., 2019; Arora et al., 2018, 2020).

The increase in the activity of antioxidant enzymes (SOD, CAT, APX and GR) is generally triggered when an excess of harmful ROS, generated under stress conditions, is detected (Shi and Zhu, 2008; Ashraf, 2009; Ahmad et al., 2010; Chan et al., 2016; Gharsallah et al., 2016). Plant species differ greatly in their responses to environmental stresses, and their ability to adapt to different abiotic stresses also depends, in many cases, on their ability to activate antioxidant enzyme systems (Kusvuran et al., 2016).

Superoxide dismutase is considered a primary line of defence against oxidative stress, as it eliminates highly reactive superoxide radicals (Huang et al., 2019). Increased SOD activity has been reported for both, water stress (Zgallaï et al., 2006; Wang and Li, 2008; Zhu et al., 2020) and salt stress in many different plant species (Carrasco-Ríos and Pinto, 2014; Evelin and Kapoor, 2014; Al Kharusi et al., 2019), as SOD is considered the most effective enzymatic antioxidant, ubiquitous in all aerobic organisms (Alscher et al., 2002; Gill and Tuteja, 2010). Catalase and ascorbate peroxide catalyse the breakdown of $\mathrm{H}_{2} \mathrm{O}_{2}$ in water and oxygen, and both play an essential role in the antioxidant system of plants (Ben-Amor et al., 2005; Omamt et al., 2006; Kangasjärvi et al., 2008). Increases in CAT activity have been described in different species (Yang et al., 2008; Chutipaijit, 2016; Plesa et al., 2018). Glutathione reductase is an essential enzyme, highly conserved in nature, responsible for the recycling of glutathione, catalysing the reduction of its oxidised form, using NADPH as cofactor (Couto et al., 2016). Increased GR activity has been reported in response to various stresses in many different plant species, e.g., in apple (Wang et al., 2013), wheat (Shan et al., 2015) or tomato (Ding et al., 2018).

The results presented here indicate that the patterns of stress-induced changes in antioxidant enzyme activities were the same for the two selected lavender cultivars since, with very few exceptions, no significant differences between LAC and LAS plants were observed in any of the control or stress treatments. Also, no significant increase in any of the enzyme activities has been detected in response to water deficit; in fact, the GR activity even decreased significantly in both lavender varieties, as reported in other species, for example in spruce seedlings (Todea et al., 2020). These data suggest that the antioxidant response to drought in lavender is primary based on the accumulation of phenolic compounds, in general, and of flavonoids, in particular, without involvement of the assayed antioxidant enzyme systems. Regarding salt stress, in addition to the accumulation of flavonoids, significant increases in SOD and CAT activities have been detected in salt-stressed plants, supporting the participation of these specific enzymes in the antioxidant defence against salt stress in $L$. angustifolia.

\section{Conclusions}

Comparative studies on the antioxidant responses of Lavandula angustifolia var. 'Codreanca' (LAC) and var. 'Sevtopolis' (LAS) to water and salt stress revealed that both varieties possess effective antioxidant mechanisms to mitigate oxidative stress associated to drought and salinity, without significant differences being observed between the two genotypes. The response to drought-induced oxidative stress is essentially based on the accumulation of antioxidant phenolics, including the subgroup of flavonoids, apparently without contribution of antioxidant enzymes. Oxidative stress caused by high salinity is partly counteracted by the synthesis of flavonoids but, in addition, by the increase of SOD and CAT specific activities. These antioxidant responses, together with previously described mechanisms based on the control of ion transport and the accumulation of the osmolyte proline, explain the relative tolerance of Lavandula angustifolia to drought and salinity. 


\section{Authors' Contributions}

Conceptualization, M.B. and M.C.; Formal analysis, M.B., O.V. and M.C.; Investigation, Z.S.-V. and S.G.-O.; Resources, O.V.; Supervision, M.B., O.V. and M.C.; Visualization, O.V.; Writing-original draft, Z.S.V.; Writing-review and editing, O.V. All authors have read and agreed to the published version of the manuscript.

\section{Acknowledgements}

Z.S.-V. was the recipient of a pre-doctoral Erasmus Mundus scholarship at the Polytechnic University of Valencia, financed by the European Commission.

\section{Conflict of Interests}

The authors declare that there are no conflicts of interest related to this article.

\section{References}

Abogadallah GM (2010). Insights into the significance of antioxidative defense under salt stress. Plant Signaling \& Behavior 5(4):369-374. https://doi.org/10.4161/psb.5.4.10873

Acosta-Motos JR, Ortuño MF, Bernal-Vicente A, Diaz-Vivancos P, Sánchez-Blanco MJ, Hernandez JA (2017). Plant responses to salt stress: Adaptive mechanisms. Agronomy 7:18. https://doi.org/10.3390/agronomy7010018

Adam KL (2006). Lavender production, products, markets, and entertainment farms, ATTRA. Retrieved 2020 July 26 from www.attra.ncat.org

Aebi $\mathrm{H}$ (1984). Catalase in vitro. Methods in Enzymology 105:121-126. https://doi.org/10.1016/S0076$6879(84) 05016-3$

Aftab T (2019). A review of medicinal and aromatic plants and their secondary metabolites status under abiotic stress. Journal of Medicinal Plants 7(3):99-106.

Ahmad P, Jaleel CA, Salem MA, Nabi G, Sharma S (2010). Roles of enzymatic and nonenzymatic antioxidants in plants during abiotic stress. Critical Reviews in Biotechnology 30(3):161-175. https://doi.org/10.3109/07388550903524243

Al Hassan M, Chaura J, Donat-Torres MP, Boscaiu M, Vicente O (2017). Antioxidant responses under salinity and drought in three closely related wild monocots with different ecological optima. AoB Plants 9(2):plx009. https://doi.org/10.1093/aobpla/plx009

Al Kharusi L, Al Yahyai R, Yaish MW (2019). Antioxidant response to salinity in salt-tolerant and salt-susceptible cultivars of date palm. Agriculture 9:8. https://doi.org/10.3390/agriculture9010008

Alscher RG, Erturk N, Heath LS (2002). Role of superoxide dismutases (SODs) in controlling oxidative stress in plants. Journal of Experimental Botany 53:1331-1341. https://doi.org/10.1093/jexbot/53.372.1331

Arora M, Saxena P, Abdin MZ, Varma A (2020). Interaction between Piriformospora indica and Azotobacter chroococcum diminish the effect of salt stress in Artemisia annua L. by enhancing enzymatic and non-enzymatic antioxidants. Symbiosis 80:61-73. https://doi.org/10.1007/s13199-019-00656-W

Arora M, Saxena P, Abdin, MZ, Varma A (2018). Interaction between Piriformospora indica and Azotobacter chroococcum governs better plant physiological and biochemical parameters in Artemisia annua L. plants grown under in vitro conditions. Symbiosis 75:103-112. https://doi.org/10.1007/s13199-017-0519-y

Ashraf M (2009). Biotechnological approach of improving plant salt tolerance using antioxidants as markers. Biotechnology Advances 27:84-93. https://doi.org/10.1016/j.biotechadv.2008.09.003

Bartels D, Ramanjulu S (2005). Drought and salt tolerance in plants. Critical Reviews in Plant Sciences 24:23-58. https://doi.org/10.1080/07352680590910410 
Bautista I, Boscaiu M, Lidón A, Llinares JV, Lull C, Donat MP, ... Vicente O (2016). Environmentally induced changes in antioxidant phenolic compounds levels in wild plants. Acta Physiologiae Plantarum 38(1):9. https://doi.org/10.1007/s11738-015-2025-2

Benabdelkader T, Zitouni A, Guitton Y, Jullien F, Maitre D, Casabianca H, ... Kameli A (2011). Essential oils from wild populations of algerian Algerian lavandula Lavandula stoechas L.: Composition, chemical variability, and in vitro biological properties. Chemistry \& Biodiversity 8:937-953. https://doi.org/10.1002/cbdv.201000301

Ben-Amor N, Hamed KB, Debez A, Grignon C, Abdelly C (2005). Physiological and antioxidant response of the perennial halophytes Crithmum maritimum to salinity. Plant Science 168:889-899. https://doi.org/10.1016/j.plantsci.2004.11.002

Beyer Jr, Wayne F, Fridovich I (1987). Assaying for superoxide dismutase activity: Some large consequences of minor changes in conditions. Analytical Biochemistry 161:559-566. https://doi.org/10.1016/0003-2697(87)90489-1

Biesiada A, Kucharska A (2008). The effect of nitrogen fertilization on yielding and antioxidant activity of lavender (Lavandula angustifolia Mill.). Acta Scientiarum Polonorum Hortorum Cultus 7(2):33-40.

Blainski A, Lopes GC, Palazzodemello JC (2013). Application and analysis of the Folin Ciocalteu method for the determination of the total phenolic content from Limonium Brasiliense L. Molecules 18:6852-6865. https://doi.org/10.3390/molecules 18066852

Bradford MM (1976). A rapid and sensitive method for the quantitation of microgram quantities of protein utilizing the principle of protein-dye binding. Analytical Biochemistry 72:248-254. https://doi.org/10.1016/00032697(76)90527-3

Cantor M, Vlas N, Szekely-Varga Z, Jucan D, Zaharia A (2018). The influence of distillation time and the flowering phenophase on quantity and quality of the essential oil of Lavandula angustifolia cv. 'Codreanca'. Romanian Biotechnological Letters 23(6):14146. https://doi.org/10.26327/RBL2018.192

Carrasco A, Martinez-Gutierrez R, Tomas V, Tudela J (2016). Lavandula angustifolia and Lavandula latifolia essential oils from Spain: Aromatic profile and bioactivities. Planta Medica 82(01/02):163-170. https://doi.org/10.1055/s-0035-1558095

Carrasco-Ríos L, Pinto M (2014). Effect of salt stress on antioxidant enzymes and lipid peroxidation in leaves in two contrasting corn, 'Lluteno' and 'Jubilee'. Chilean Journal of Agricultural Research 74(1):89-95. https://dx.doi.org/10.4067/S0718-58392014000100014

Chan Z, Yokawa K, Kim W-Y, Song C-P (2016). ROS Regulation during plant abiotic stress responses. Frontiers in plant science 7:1536. https://doi.org/10.3389/fpls.2016.01536

Chutipaijit S (2016). Changes in physiological and antioxidant activity of indica rice seedlings in response to mannitolinduced osmotic stress. Chilean Journal of Agricultural Research 76(4):455-462. https://dx.doi.org/10.4067/S0718-58392016000400009

Conell JP, Mullet JE (1986). Pea chloroplast glutathione reductase: Purification and characterization Plant Physiology 82:351-356. https://doi.org/10.1104/pp.82.2.351

Couto N, Wood J, Barber J (2016). The role of glutathione reductase and related enzymes on cellular redox homoeostasis network. Free Radical Biology and Medicine 95:27-42. https://doi.org/10.1016/j.freeradbiomed.2016.02.028

Croitoru AE, Piticar A, Burada DC (2016). Changes in precipitation extremes in Romania. Quaternary International 415:325-335. https://doi.org/10.1016/j.quaint.2015.07.028

Del Rio LA, Palma JM, Sandalio LM, Corpas GM, Bueno P, López-Huertas E (1996). Peroxisomes as a source of superoxide and hydrogen peroxide in stressed plants. Biochemical Society Transactions 24:434-438. https://doi.org/10.1042/bst0240434

Ding F, Wang G, Wang M, Zhang S (2018). Exogenous melatonin improves tolerance to water deficit by promoting cuticle formation in tomato plants. Molecules 23:1605. https://doi.org/10.3390/molecules23071605

Evelin H, Kapoor R (2014). Arbuscular mycorrhizal symbiosis modules antioxidant response in salt stressed Trigonella foenum-graecum plants. Mycorrhiza 24:197-208. https://doi.org/10.1007/s00572-013-0529-4

Fahad S, Bajwa AA, Nazir U, Anjum SA, Farooq A, Zohaib A, ... Ihsan MZ (2017). Crop production under drought and heat stress: plant responses and management options. Frontiers in Plant Science 8:1147. https://doi.org/10.3389/fpls.2017.01147

Forni C, Duca D, Glick BR (2016). Mechanisms of plant response to salt and drought stress and their alteration by rhizobacteria. Plant and Soil 410:335-356. https://doi.org/10.1007/s11104-016-3007-X 
Gharsallah C, Fakhfakh H, Grubb D, Gorsane F (2016). Effect of salt stress on ion concentration, proline content, antioxidant enzyme activities and gene expression in tomato cultivars. AoB Plants 8 . https://doi.org/10.1093/aobpla/plw055

Gil R, Bautista I, Boscaiu M, Lidón A, Wankhade S, Sánchez H, ... Vicente O (2014). Responses of five Mediterranean halophytes to seasonal changes in environmental conditions. AoB Plants 6. https://doi.org/10.1093/aobpla/plu049

Gill SS, Tuteja N (2010). Reactive oxygen species and antioxidant machinery in abiotic stress tolerance in crop plants. Plant Physiology and Biochemistry 48:909-930. https://doi.org/10.1016/j.plaphy.2010.08.016

Goharrizi KJ, Moosavi SS, Amirmahani F, Salehi F, Nazari M (2020). Assessment of changes in growth traits, oxidative stress parameters, and enzymatic and non-enzymatic antioxidant defense mechanisms in Lepidium draba plant under osmotic stress induced by polyethylene glycol. Protoplasma 257:459-473. https://doi.org/10.1007/s00709-019-01457-0

Hendawy SF, Khalid KA (2005). Response of sage (Salvia officinalis L.) plants to zinc application under different salinity levels. Journal of Applied Sciences Research 1:147-155.

Hoagland DR, Arnon DI (1950). The water-culture method for growing plants without soil. In California Agricultural Experiment Station Publications Series; College of Agriculture, University of California: Davis, CA, USA.

Hodges DM, Delong JM, Forney CF, Prange RK (1999). Improving the thiobarbituric acid-reactive-substances assay for estimating lipid peroxidation in plant tissues containing anthocyanin and other interfering compounds. Planta 207:604-611. https://doi.org/10.1007/s004250050524

Huang H, Ullah F, Zhou D-X, Yi M, Zhao Y (2019). Mechanisms of ROS regulation of plant development and stress responses. Frontiers in Plant Science 10:800. https://doi.org/10.3389/fpls.2019.00800

Hussain M, Park HW, Farooq M, Jabran K, Lee DJ (2013). Morphological and physiological basis of salt resistance in different rice genotypes. International Journal of Agriculture and Biology 15:113-118.

Irimia LM, Patriche CV, Roșca B (2018). Climate change impact on climate suitability for wine production in Romania. Theoretical and Applied Climatology 133(1-2):1-14. https://doi.org/10.1007/s00704-017-2156-z

Kangasjärvi S, Lepistö A, Hännikäinen K, Piippo M, Luomala EM, Aro EM, Rintamäki E (2008). Diverse roles for chloroplast stromal and thylakoidbound ascorbate peroxidases in plant stress responses. Biochemical Journal 412:275-285. https://doi.org/10.1042/BJ20080030

Kaur G, Asthir B (2016). Molecular responses to drought stress in plants. Biologia Plantarum 61(2):201-209. https://doi.org/10.1007/s10535-016-0700-9

Kıvrak Ş (2018). Essential oil composition and antioxidant activities of eight cultivars of Lavender and Lavandin from western Anatolia. Industrial Crops and Products, 117:88-96. https://doi.org/10.1016/j.indcrop.2018.02.089

Koulivand PH, Ghadiri MK, Gorji A (2013). Lavender and the nervous system. Evidence-Based Complementary and Alternative Medicine 10. https://doi.org/10.1155/2013/681304

Kusvuran S, Kiran S, Ellialtioglu SS (2016). Antioxidant enzyme activities and abiotic stress tolerance relationship in vegetable crops. Abiotic and biotic stress in plants-recent advances and future perspectives, 1st ed.; InTech: Croatia pp 481-503.

Lis-Balchin M (2002). Lavender: The genus Lavandula. Taylor and Francis Inc. (1st ed), New York.

Lis-Balchin M (2012). Lavender. In: Handbook of Herbs and Spices. Elsevier, Amsterdam, The Netherlands, pp 329-347. Matysiak B, Nogowska A (2016). Impact of fertilization strategies on the growth of lavender and nitrates leaching to environment. Horticultural Science 43(2):76-83. https://doi.org/10.17221/12/2015-HORTSCI

Meier U (2001). Growth stages of mono-and dicotyledonous plants. BBCH Monograph Federal Biological Research Centre for Agriculture and Forestry (2nd ed), Germany.

Miller G, Shulaev V, Mittler R (2008). Reactive oxygen signalling and abiotic stress. Physiologia Plantarum 133(3):481489. https://doi.org/10.1111/j.1399-3054.2008.01090.x

Mittal N, Thakur S, Verma H, Kaur A (2018). Interactive effect of salinity and ascorbic acid on Brassica rapa L. plants. Global Journal of Bio-Science and Biotechnology 7:27-29.

Mokhtarzadeh S, Hajyzadeh M, Ahmad H, Khawar KM (2013). The problems in acclimatisation of in vitro multiplied plants of Lavandula angustifolia Miller under field conditions. Journal of Biotechnology 988:71-76. https://doi.org/10.17660/actahortic.2013.988.6

Morales M, Munné-Bosch S (2019). Malondialdehyde: Facts and artifacts. Plant Physiology 180(3):1246-1250. https://doi.org/10.1104/pp.19.00405 
Munns R, Tester M (2008). Mechanisms of salinity tolerance. Annual Review of Plant Biology 59:651-681. https://doi.org/10.1146/annurev.arplant.59.032607.092911

Nakano Y, Asada K (1981). Hydrogen peroxide is scavenged by ascorbate specific peroxidase in spinach chloroplasts. Plant and Cell Physiology 22:867-888. https://doi.org/10.1093/oxfordjournals.pcp.a076232

Nareshkumar A, Subbarao S, Vennapusa AR, Ashwin V, Banarjee R, Kulkarni MJ, ... Udayakumar M (2020). Enzymatic and non-enzymatic detoxification of reactive carbonyl compounds improves the oxidative stress tolerance in cucumber, tobacco and rice seedlings. Journal of Plant Growth Regulation 39:1359-1372. https://doi.org/10.1007/s00344-020-10072-W

Omamt EN, Hammes PS, Robbertse PJ (2006). Differences in salinity tolerance for growth and water-use efficiency in some amaranth (Amaranthus spp.) genotypes. New Zealand Journal of Crop and Horticultural Science 34:1122. https://doi.org/10.1080/01140671.2006.9514382

Pisulewska E, Puchalska H, Zaleski T, Janeczko Z (2009). Effect of environmental conditions on yield and quality of narrow-leaved lavender (Lavandula angustifolia Mill). Ecological Chemistry and Engineering 16(7):845-854.

Plesa IM, González-Orenga S, Al Hassan M, Sestras AF, Vicente O, Prohens J, ... Boscaiu M (2018). Effects of drought and salinity on European larch (Larix decidua Mill.) seedlings. Forests 9:320, https://doi.org/10.3390/f9060320

Prăvălie R, Sîrodoev I, Patriche C, Roșca B, Piticar A, Bandoc G, ... Mănoiu V (2020). The impact of climate change on agricultural productivity in Romania. A country-scale assessment based on the relationship between climatic water balance and maize yields in recent decades. Agricultural Systems 179:102767. https://doi.org/10.1016/j.agsy.2019.102767

Prusinowska R, Śmigielski KB (2014). Composition, biological properties and therapeutic effects of lavender (Lavandula angustifolia L). A review. Herba Polonica 60(2):56-66. https://doi.org/10.2478/hepo-2014-0010

Rao MPN, Dong Z-Y, Xiao M, Li W-J (2019). Effect of salt stress on plants and role of microbes in promoting plant growth under salt stress. In: Biocontrol of Lepidopteran Pests, Springer: Cham, Germany pp 423-435. https://doi.org/10.1007/978-3-030-18975-4_18

Rodríguez-Calzada T, Qian M, Strid Å, Neugart S, Schreiner M, Torres-Pacheco I, Guevara-González RG (2019). Effect of UV-B radiation on morphology, phenolic compound production, gene expression, and subsequent drought stress responses in chili pepper (Capsicum annuum L.). Plant Physiology and Biochemistry 134:94-102. https://doi.org/10.1016/j.plaphy.2018.06.025

Seidler-Àoīykowska K, Mordalski R, Kucharski W, Kćdzia B, Bocianowski J (2014). Yielding and quality of lavender flowers (Lavandula angustifolia Mill.) from organic cultivation. Acta Scientarum Polonorum Hortorum Cultus 13(6):173-183.

Shah A, Smith DL (2020). Flavonoids in agriculture: chemistry and roles in biotic and abiotic stress responses, and microbial associations. Agronomy 10:1209. https://doi.org/10.3390/agronomy10081209

Shan C, Zhou Y, Liu M (2015). Nitric oxide participates in the regulation of the ascorbate-glutathione cycle by exogenous jasmonic acid in the leaves of wheat seedlings under drought stress. Protoplasma 252(5):1397-1405. https://doi.org/10.1007/s00709-015-0756-y

Sharma P, Jha AB, Dubey RS, Pessarakli M (2012). Reactive oxygen species, oxidative damage, and antioxidative defense mechanism in plants under stressful conditions. Journal of Botany 26. https://doi.org/10.1155/2012/217037

Sharma P, Kharkwal AC, Abdin MZ, Varma A (2016). Piriformospora indica-mediated salinity tolerance in Aloe vera plantlets. Symbiosis 72:103-115. https://doi.org/10.1007/s13199-016-0449-0

Shi QH, Zhu ZJ (2008). Effects of exogenous salicylic acid on manganese toxicity, element contents and antioxidative system in cucumber. Environmental and Experimental Botany 63:317-326. https://doi.org/10.1016/j.envexpbot.2007.11.003

Szekely-Varga Z, González-Orenga S, Cantor M, Jucan D, Boscaiu M, Vicente O (2020). Effects of drought and salinity on two commercial varieties of Lavandula angustifolia Mill. Plants 9:637. https://doi.org/10.3390/plants9050637

The Plant List, Version 1, Published on the Internet. Retrieved 2020 July 27 from http://www.theplantlist.org

Todea (Morar) IM, González-Orenga S, Boscaiu M, Plazas M, Sestras AF, Prohens J, ... Sestras RE (2020). Responses to water deficit and salt stress in silver fir (Mill.) seedlings. Forests 11:395. https://doi.org/10.3390/f11040395

Upson T, Andrews S (2004). The genus Lavandula. Timber Press Inc. (1st ed), USA.

Van Breusegem F, Vranová E, Dat Jf, Inzé D (2001). The role of active oxygen species in plant signal transduction. Plant Science 161:405-414. https://doi.org/10.1016/S0168-9452(01)00452-6 
Wang CQ, Li RC (2008). Enhancement of superoxide dismutase activity in the leaves of white clover (Trifolium repens L.) in response to polyethylene glycol-induced water stress. Acta Physiologiae Plantarum 30:841-847. http://doi.org/10.1007/s11738-008-0189-8

Wang P, Sun X, Li C, Wei Z, Liang D, Ma F (2013). Long-term exogenous application of melatonin delays droughtinduced leaf senescence in apple. Journal of Pineal Research 54:292-302. https://doi.org/10.1111/jpi.12017

Wells R, Truong F, Adal AM, Sarker LS, Mahmoud SS (2018). Lavandula essential oils: a current review of applications in medicinal, food, and cosmetic industries of lavender. Natural Product Communications 13(10):1403-1417. https://doi.org/10.1177/1934578X1801301038

Xia H, Ni Z, Hu R, Lin L, Deng H, Wang J, ... Liao M (2020). Melatonin alleviates drought stress by a non-enzymatic and enzymatic antioxidative system in kiwifruit seedlings. International Journal of Molecular Sciences 21(3):852. https://doi.org/10.3390/ijms21030852

Yang Y, Han C, Liu Q, Lin B, WangJ (2008). Effect of drought and low light on growth and enzymatic antioxidant system of Picea asperata seedlings. Acta Physiologiae Plantarum 30:433-440. http://doi.org/10.1007/s11738-008O140-Z

Zgallaï H, Stepp K, Lemeur R (2006). Effects of different levels of water stress on leaf water potential, stomatal resistance, protein and chlorophyll content and certain anti-oxidative enzymes in tomato plants. Journal of Integrative Plant Biology 48:679-685. https://doi.org/10.1111/j.1744-7909.2006.00272.x

Zhishen J, Mengcheng T, Jianming W (1999). The determination of flavonoid contents in mulberry and their scavenging effects on superoxide radicals. Food Chemistry 64:555-559. https://doi.org/10.1016/S0308-8146(98)00102-2

Zhou C, Busso CA, Yang YG, Zhang Z, Wang ZW, Yang YF, Han XG (2017). Effect of mixed salt stress on malondialdehyde, proteins and antioxidant enzymes of Leymus chinensis in three leaf colors. Phyton International Journal of Experimental Botany 86:205-213.

Zhu Y, Luo X, Nawaz G, Yin J, Yang J (2020). Physiological and biochemical responses of four cassava cultivars to drought stress. Scientific Reports 10(1):6968. https://doi.org/10.1038/s41598-020-63809-8
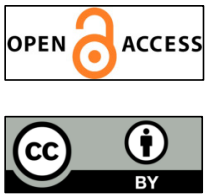

The journal offers free, immediate, and unrestricted access to peer-reviewed research and scholarly work. Users are allowed to read, download, copy, distribute, print, search, or link to the full texts of the articles, or use them for any other lawful purpose, without asking prior permission from the publisher or the author.

License - Articles published in Notulae Botanicae Horti Agrobotanici Cluj-Napoca are Open-Access, distributed under the terms and conditions of the Creative Commons Attribution (CC BY 4.0) License.

(c) Articles by the authors; UASVM, Cluj-Napoca, Romania. The journal allows the author(s) to hold the copyright/to retain publishing rights without restriction. 